\title{
ASMENŲ, TURINČIŲ ŠIZOFRENIJOS SPEKTRO PSICHIKOS SUTRIKIMŲ, VEIKSNUMO APRIBOJIMAS
}

\author{
Jelena Daškevičienė $\dot{1}^{1,2}$, Konstantinas Daškevičius ${ }^{1}$, Gintarẻ Navickaitė ${ }^{3}$ \\ ${ }^{1}$ Nepriklausoma teismo psichiatrijos tarnyba, ${ }^{2}$ Lietuvos sveikatos mokslu universiteto \\ Medicinos akademijos Psichiatrijos klinika, ${ }^{3}$ Vilniaus universiteto Medicinos fakultetas
}

Raktažodžiai: teismo psichiatrijos ekspertizè civilinėse bylose, fizinio asmens pripažinimas neveiksniu, veiksnumo apribojimas.

\begin{abstract}
Santrauka
Veiksnumas yra svarbiausias teisinio subjektiškumo elementas, susijęs su asmens galimybėmis atlikti tam tikrus veiksmus. Civiliniuose teisiniuose santykiuose dalyvauja visi žmonès, taip pat ir asmenys, turintys psichikos sutrikimų, todèl teismo psichiatrijos ekspertizè civiliniame procese yra susijusi su socialiai reikšmingomis psichikos sutrikimus lydinčiomis gyvenimo situacijomis, kuomet ekspertas vertina asmens socialinį buitinị funkcionavimą ir faktinę adaptaciją. Nuo 2016 m. ịsigaliojus LR Civilinio kodekso pataisoms dèl fizinio asmens pripažinimo neveiksniu tam tikroje srityje, Lietuvoje vyksta visų asmenų, kurie iki 2016 $\mathrm{m}$. buvo pripažinti neveiksniais, teismų sprendimų peržiūra bei kitų asmenų, turinčių psichikos sutrikimų, veiksnumo apribojimas pagal tam tikras gyvenimo sritis. Mūsų darbo tikslas buvo atlikti asmenų, turinčių šizofrenijos spektro sutrikimų, kurių atžvilgiu buvo pradètas civilinis procesas dẻ jų veiksnumo apribojimo ar ankstesnès teismo sprendimo peržiūros, psichikos sveikatos būklès vertinimą ir išskirti pagrindinius kriterijus, vertinant jų gebejjimą suprasti savo veiksmų reikšmę ir juos valdyti konkrečioje gyvenimo srityje. Nustatyta, kad pagrindinis vertinimo kriterijus yra klinikinis, tai yra aktyvios psichopatologijos intensyvumo, sutrikimo eigos, gydymo efektyvumo, kritinių gebejjimų savo psichikos sveikatos atžvilgiu vertinimas bei socialinės adaptacijos lygis. Tyrimo metu taip pat buvo nustatyta, kad šizofrenijos spektro sutrikimus turintiems asmenims institucinè globa turi žymiai daugiau teigiamos įtakos užtikrinant šių asmenų psichikos sveikatos stabilumą, gydymo tęstinumą, buitines ir socialines garantijas bei
\end{abstract}

jų adaptaciją kasdieniniame gyvenime, palyginus su psichikos sveikata ir gyvenimo kokybe asmenų, gyvenančių savarankiškai. Priimant ekspertinị sprendimą dèl gebejjimo iš dalies suprasti savo veiksmų esmę ir juos valdyti, šiai diagnostinei tiriamujų asmenų grupei lemiamu argumentu buvo asmens gebejjimas ir motyvacija priimti pagalbą. Teismo psichiatrai ekspertai, atlikdami šios rūšies ekspertizes, privalo vadovautis nuostata dèl asmens maksimalaus veiksnumo išsaugojimo.

\section{Ivadas}

2010 m. Lietuvai ratifikavus 2006 m. gruodžio 13 d. priimtą Jungtinių Tautų Neiggaliųjų teisių konvenciją, kurios 12 straipsnio 2 dalis skelbia principinę nuostatą, kad „valstybės, šios Konvencijos Šalys, pripažįsta, kad neịgalieji turi teisini veiksnumą lygiai su kitais asmenimis visose gyvenimo srityse"[1]. Siekiant Jungtinių Tautų Neiggaliujų teisių konvencijos igyvendinimo, Lietuvoje buvo pakeisti asmens pripažinimo neveiksniu ir veiksnumo apribojimo institutai. LR Civilinio kodekso ir LR Civilinio proceso kodekso straipsniuose numatyta pagrindinè naujovè - fizinių asmenu pripažinimas neveiksniu ar ribotai veiksniu konkrečiose gyvenimo srityse. Be to, fizinių asmenų veiksnumas gali būti apribotas bet kokị psichikos sutrikimą turintiems asmenims, kurie dèl psichikos sutrikimo gali tik iš dalies suprasti savo veiksmų reikšmę ar juos valdyti. Toks ịstatymo pakeitimas lėmè asmenų, turinčių psichikos sutrikimą, teisių reikšmingą praplètimą.

Pažymètina ir tai, kad be minètosios Jungtinų Tautų Neigaliujų teisių konvencijos egzistuoja nemažai nacionalinių, Europos Sajungos bei tarptautinių teisès aktų, užkertančių kelią piktnaudžiauti asmens neveiksnumu. Štai Visuotinès žmogaus teisių deklaracijos 6 straipsnis skelbia, kad „kiekvienas, kad ir kur būtų, turi teisę būti pripažintas teisinių santykių subjektu“, o 22 straipsnyje įtvirtinta, kad „kiekvienas asmuo, kaip visuomenès narys, turi teisę ị socialinę apsaugą ir teisę, 
kad valstybės pastangomis bei bendradarbiaujant tarptautiniu lygiu ir pagal kiekvienos valstybès struktūrą bei išteklius būtų igyvendinamos jo orumui ir laisvam asmenybės vystymuisi būtinos ekonominès, socialinès ir kultūrinès teisès" [2]. Remiantis Europos žmogaus teisių ir pagrindinių laisvių apsaugos konvencijos 8 straipsnio 1 dalimi, ,kiekvienas asmuo turi teisę ị tai, kad būtų gerbiamas jo asmeninis ir jo šeimos gyvenimas, buto neliečiamybe ir susirašinejjimo slaptumas“ [3]. Europos Tarybos Ministrų Komiteto rekomendacijoje dèl Pilnamečių neveiksnių asmenų teisinès apsaugos principų yra ịtvirtintas labai svarbus sutrikusios psichikos asmenu veiksnumo maksimalaus išsaugojimo principas, pagal kurị, atsižvelgiant ị tai, kad gali egzistuoti ịvairaus laipsnio nesugebejjimas suprasti savo veiksmų reikšmès ar jų valdyti, ir jis gali kisti, net ir visiškai sutrikusios psichikos asmenų teisinio veiksnumo atemimas, kaip jų teisinès apsaugos priemonių igyvendinimo rezultatas, neturètų būti neišvengiamas [4].

Taigi, nuo $2016 \mathrm{~m}$. sausio $1 \mathrm{~d}$. ịsigaliojo LR Civilinio kodekso 2.10 straipsnio dèl fizinio asmens pripažinimo neveiksniu tam tikroje srityje redakcija, kurioje nurodyta:

1) fizinis asmuo, kuris dèl psichikos sutrikimo negali suprasti savo veiksmų tam tikroje srityje reikšmès ar jų valdyti, gali būti teismo tvarka pripažintas neveiksniu toje srityje, neveiksniam tam tikroje srityje asmeniui šioje srityje yra nustatoma globa;

2) teismas sprendime nurodo baigtinị sričių, kuriose asmuo pripažizstamas neveiksniu, sąrašą, pripažinto neveiksniu tam tikroje srityje asmens vardu sandorius toje srityje sudaro jo globejjas, jo teises ir pareigas nustato šio kodekso trečiosios knygos normos;

3) jeigu pripažintas neveiksniu tam tikroje srityje asmuo pasveiksta arba jo sveikata labai pagerèja, teismas pripažista ji veiksniu toje srityje, ịsiteisèjus teismo sprendimui, tokiam asmeniui nustatyta globa toje srityje pasibaigia;

4) neveiksniu tam tikroje srityje pripažintam asmeniui teisès aktuose nustatytos neveiksnumo teisinès pasekmès atsiranda tik toje srityje [5].

LR Civilinio kodekso 1.85 str. numatyta galimybe apriboti veiksnumą tam tikroje gyvenimo srityje, vadovaujantis asmens gebejjimo pasirūpinti savimi ir priimti kasdienius sprendimus nustatymo tvarkos aprašu, patvirtintu $2015 \mathrm{~m}$. gruodžio $10 \mathrm{~d}$. socialinès apsaugos ir darbo ministro įsakymu Nr. A1-742:

1. Turtinių santykių sritys:

1) asmeninių pajamų ir išlaidų tvarkymas, susijęs su smulkiais buitiniais sandoriais (maisto produktų įsigijimas, sumokejjimas už komunalines paslaugas ir pan.);

2) asmeninių pajamų ir išlaidų tvarkymas, susijęs su lizingu, daiktų pirkimo-pardavimo išsimokètinai sutarčių sudarymu, paskolų, vartojimo kreditų sutarčių sudarymu ir pan.;
3) kilnojamo turto naudojimas, valdymas ir disponavimas (kilnojamojo turto pirkimo-pardavimo, nuomos, dovanojimo, ikeitimo sandoriai ir kt.);

4) nekilnojamo turto naudojimas, valdymas ir disponavimas (nekilnojamojo turto pirkimo-pardavimo, nuomos, dovanojimo, įkeitimo sandoriai ir kt.);

5) paveldejimo teisiniai santykiai (palikimo prièmimas, testamento sudarymas ir kt.);

6) dalyvavimas ūkinejje-komercinèje veikloje (juridiniu asmenu steigimas, buvimas juridinio asmens dalyviu, vertimasis individualia veikla ir kt.);

7) kitos sritys.

2. Asmeninių neturtinių santykių sritys:

1) savitvarkos ịūdžiu sritis (tinkama gyvenamojo būsto priežiūra ir pan.);

2) sveikatos priežiūros sritis (kreipimasis dèl sveikatos priežiūros paslaugų, gebėjimas naudotis sveikatos priežiūros paslaugomis, reikiamo sveikatos priežiūros paslaugų poreikio įvertinimas ir pan.);

3) šeimos santykių sritis (santuokos sudarymas, asmens gebejjimas igyvendinti tèvų valdžią - auklèti ir prižiūrèti savo vaikus, ịvaikinti ir kt.);

4) asmens gebèjimas būti globèju (rūpintoju), pagalbininku pagal sutartị dèl pagalbos priimant sprendimus;

5) darbo teisinių santykių sritis;

6) pilietinių teisių sritis (balsavimo teisè);

7) kitos sritys [6].

Teismo psichiatrijos ekspertizės metu padarytas sprendimas dèl tiriamojo asmens veiksnumo apribojimo reiškia, kad toks asmuo pats savarankiškai nesugeba suprasti savo veiksmų reikšmės ir jų valdyti konkrečioje gyvenimo srityje. Ši galimybė jam atsiranda tik rūpintojo ar globejjo pagalba.

Atliekant teismo psichiatrijos ekspertizę bylose dèl asmens pripažinimo veiksniu, ribotai veiksniu ar neveiksniu tam tikrose srityse, ekspertinis sprendimas priklauso ne tik nuo psichikos sutrikimo sunkumo, bet ypač nuo klinikinių dinaminių pokyčių, leidžiančių prognozuoti tiriamojo tolimesnę veiklą, jo galimybes adekvačiai suvokti aplinkinị pasaulị ir atitinkamai elgtis. Taip pat svarbūs yra ir socialiniai faktoriai, apibūdinantys asmens socialinị buitinị funkcionalumą ir faktinę adaptaciją. Šizofrenijos spektro sutrikimus turinčių asmenų teismo psichiatrinis ịvertinimas civilinėje teisès situacijoje šiuo metu vykdomas labai plačiu diapazonu, nuo besąlyginio šios diagnozès tapatinimo su visišku asmens neveiksnumu iki diferencinio požiūrio ị atskirus remisijos variantus, kurių metu ịmanomas ịvairus sugebejjimo lygis suvokti savo veiksmų esmę ir juos valdyti buitineje ir socialinėje aplinkoje.

Turint gan nemažą patirtí, atliekant šios rūšies teismo psichiatrijos ekspertizes bei remiantis naujomis LR CK pa- 
taisomis, galime teigti, kad daugiausia sunkumų patiriame sprendžiant veiksnumo apribojimo klausimą asmenims, turintiems šizofrenijos spektro sutrikimų. Nuolat kyla dilema, ar teismo psichiatras ekspertas apskritai turi moralinę teisę daryti įtaką socialinei žmogaus patirčiai bei reikšmingai koreguoti jo socialinị elgesị. Teismo psichiatrams ekspertams tenka nuolat kurti tokių asmenų socialinio elgesio ,absoliučius" standartus, taip pat vertinti, ar tiriamojo asmens socialinis gyvenimas prasilenkia su tais standartais, ir drauge koreguoti standartams neatitinkančių konkrečių asmenų socialinį elgesị, tai yra daryti tiesioginę įtaką žmogaus teisèms ir jo socialiniam statusui.

Darbo tikslas - atlikti asmenų, turinčių šizofrenijos spektro sutrikimų, kurių atžvilgiu buvo pradètas civilinis procesas dèl jų veiksnumo apribojimo, socialinès adaptacijos galimybių įvertinimą ir nustatyti gebejimo suprasti savo veiksmų reikšmę ir juos valdyti konkrečioje gyvenimo srityje vertinimo kriterijus.

\section{Darbo objektas ir metodai}

Šiam darbui buvo panaudoti nuo 2016 metų iki 2018 m. liepos 1 d., tai yra 2,5 metų Nepriklausomoje teismo psichiatrijos tarnyboje atliktų ambulatorinių ekspertizių aktai (forma Nr. 192/a) (N=171), kuomet ekspertizès metu asmenims buvo diagnozuoti šizofreninio spektro sutrikimai ir šiems asmenims buvo rekomenduota apriboti veiksnumą pagal gyvenimo sritis. Informacijos atranka atlikta pagal šio darbo autorių sudarytą specialujji klausimyną.

Statistinè duomenų analizè (pateikti absoliutūs ir procentiniai dažniai) atlikta naudojant statistinès analizès SPSS programini paketą. Statistiškai reikšminga laikẻme $\mathrm{p}$ - reikšmę $<0,05$.

\section{Tyrimo rezultatai ir aptarimas}

Buvo išanalizuoti $\mathrm{N}=826(100 \%)$ teismo psichiatrijos ekspertizès aktai bei ekspertiniai sprendimai, kuomet ekspertizès metu teismui buvo rekomenduota šiuos asmenis pripažinti veiksniais, ribotai veiksniais ar neveiksniais tam tikrose gyvenimo srityse.

2016-01-01 - 2018-07-01, atliekant teismo psichiatrijos ekspertizę civiliniame procese, iš 826 atvejų 49 proc. $(\mathrm{N}=400)$ asmenų buvo diagnozuoti organiniai ir simptominiai psichikos sutrikimai, antrą pagal dydi grupę sudarè asmenys, turintys įvairaus lygio protinį atsilikimą -29 proc. $(\mathrm{N}=242)$, o 21 proc. $(\mathrm{N}=171)$ atvejų - šizofrenijos spektro sutrikimai, iš jų: 96 proc. $(\mathrm{N}=168)$ sudare šizofreniją turintys asmenys, 2 proc. $(\mathrm{N}=4)$ - šizoafektinį sutrikimą ir $\sim 2 \%(\mathrm{~N}=3)$ - šizotipinị sutrikimą.

Taigi, mūsų tyrimo objektas buvo 171 (100 proc.) šizofrenijos spektro sutrikimais sergantis asmuo, iš jų 63 proc.
(N=108) tiriamujų, kurie iki 2016 metų buvo pripažinti neveiksniais, o šiuo metu buvo atliekama ankstesnio teismo sprendimo peržiūra.

Tyrimo metu atlikta statistinė analizė suteikè galimybę sudaryti šios diagnostinès grupès asmenų socialinę charakteristiką, kuri parodè:

Iš $171(100 \%)$ šizofrenijos spektro sutrikimus turinčių asmenu 37 proc. $(\mathrm{N}=64)$ asmenų teismo sprendimu buvo paskirta institucinè globa.

Darbingumo lygis buvo įvertintas tik 51 proc. $(\mathrm{N}=87)$ asmenų, iš jų:

- iki 35 proc. netektas darbingumas buvo nustatytas 23 proc. $(\mathrm{N}=20)$ asmenu,

- iki 65 proc. netektas darbingumas nustatytas 30 proc. $(\mathrm{N}=26)$ asmenu,

- iki 85 proc. netektas darbingumas nustatytas 45 proc. $(\mathrm{N}=39)$ asmenu,

- iki 100 proc. netektas darbingumas nustatytas tik 2 proc. $(\mathrm{N}=2)$ asmenų.

3. Nuolatinis specialusis slaugos poreikis dèl psichikos sveikatos buvo nustatytas tik 16 proc. $(\mathrm{N}=28)$ asmenų bei nuolatinis specialusis priežiūros (pagalbos) poreikis - tik 12 proc. $(\mathrm{N}=21)$ asmenų.

Analizuojant tiriamųų gydymą ambulatorinėse ar stacionarinèse psichiatrijos įstaigose nustatyta, kad 68 proc. $(\mathrm{N}=117)$ asmenų buvo nuolat taikytas aktyvus gydymas psichotropiniais medikamentais, tačiau teismo psichiatrijos ekspertizès metu 74 proc. $(\mathrm{N}=126)$ tiriamujų buvo konstatuota aktyvi psichopatologija, tai yra ịvairaus pobūdžio kliedejjimo idèjos ir/ar haliucinacijos. Be to, 70 proc. $(\mathrm{N}=119)$ asmenų stebèta ryški šizofrenijos pobūdžio negatyvi simptomatika, tai yra defektas mąstymo, emocijų ir valios sferose bei menkas socialinių ryšiu palaikymas.

Atkreiptinas dėmesys ị tai, kad 37 proc. $(\mathrm{N}=64)$ asmenų, kuriems teismo sprendimu buvo paskirta institucinè globa, reikšmingai skyrèsi praktiškai visuose parametruose nuo 63 proc. $(\mathrm{N}=107)$ asmenų, gyvenančių bendruomenėje ar prižiūrimų artimujų:

- teismo sprendimo peržiūra buvo inicijuota ar atlikta daugiausia socialinių namų globotiniams (87 proc.) ir tik 13 proc. peržiūra buvo atlikta gyvenantiems artimujų priežiūroje ar bendruomeneje;

- iš viso darbingumo lygis buvo įvertintas 83 proc. asmenų, kuriems paskirta institucinè globa, o tik 9 proc. asmenų, gyvenantiems bendruomenejje;

- nuolatinis specialusis ar priežiūros (pagalbos) poreikis dèl psichikos sveikatos globos namų gyventojams buvo ịvertintas 81 proc. asmenų, o kitoje grupeje - tik 6 proc. asmenų.

Praktiškai visiems institucinę globą turintiems asmenims pagal poreikius buvo taikytas gydymas psichotropiniais me- 
dikamentais, o gyvenantiems bendruomenejje - tik 21 proc. asmenų. Dẻl šių priežasčių teismo psichiatrinès ekspertizès metu buvo stebimas akivaizdus psichikos būsenų skirtumas. Turintiems institucinę globą aktyvi psichopatologija buvo nustatyta 26 proc. asmenų, o gyvenantiems bendruomeneje net 74 proc. asmenų. Ryški šizofrenijos pobūdžio negatyvi simptomatika pasiskirste beveik panašiai: 47 proc. asmenų, turinčių institucinę globą ir 53 proc. asmenų gyvenančių bendruomeneje.

Pažymètina tai, kad atlikdami ekspertizes asmenims, turintiems institucinę globą, susiduriame su gan dideliu jų artimujų pasipriešinimu, kai rekomenduojame teismui pripažinti tiriamuosius veiksniais ar ribotai veiksniais. Buvo atvejų, kai viešai, tai yra teismo posedžio metu, ekspertams buvo grasinama susidorojimu, kreipiantis ị Sveikatos apsaugos ministeriją, ị Seimą, į žiniasklaidą. To priežastimi yra tai, kad paprastai šizofrenija sergančiụjų asmenų artimieji nenori, kad jie grįžtų iš globos ịstaigų gyventi namo, o atstačius veiksnumą tokia galimybė jiems realiai atsiranda. Reikia pažymèti, kad mūsų praktikoje teisèjai nei karto nepasidavė artimujų spaudimui ir priiminejjo sprendimus tiriamujų naudai, remdamiesi ekspertine išvada. Atliekant ekspertizes šizofrenija sergantiems asmenims, gyvenantiems bendruomenejje, nustatyta, kad net 87 proc. asmenų šeimos narių praktiškai buvo palikti ,likimo valiai“, tai yra artimieji su jais nepalaikydavo net formalių kontaktų, jiems nepadėdavo ir visiškai jais nesirūpindavo, praktiškai užmiršdavo apie jų egzistavimą. Dèl tokių asmenų veiksnumo apribojimo paprastai kreipiasi prokuratūra, socialinès tarnybos ar šalia jų gyvenantys kaimynai. Teismas turi nemažai sunkumų parenkant tokiems asmenims globejjus, nes paprastai artimieji atsisako juos globoti, o jie patys kategoriškai atsisako institucinès globos, todèl teismo psichiatrams ekspertams tenka spręsti klausimą dèl šių asmenų gebėjimo suprasti savo veiksmų esmę ir juos valdyti pasirenkant gyvenamają vietą, ir tuomet turime didžiuli tiriamujjų nepasitenkinimą.

Šiame darbe taip pat buvo atlikta socialinių darbuotojų îvertinimo rezultatų dẻl asmens gebejjimo pasirūpinti savimi ir priimti kasdienius sprendimus ivvairiose gyvenimo srityse ir Nepriklausomos teismo psichiatrijos tarnybos ekspertų sprendimų palyginamoji analize, kurios metu buvo nustatytas ryškus išvadų nesutapimas (1-3 lentelès).
Buvo atkreiptas dèmesys ị socialinių darbuotojų teismui pateiktų išvadų argumentaciją, kuomet nustatyta gan abejotina šių išvadų motyvacija (pvz.: tiriamasis geba iš dalies savarankiškai, naudodamasis pagalba, pasirūpinti savimi ir priimti kasdienius sprendimus savitvarkos srityje, nes skiria dieną nuo nakties; tiriamasis geba iš dalies savarankiškai, naudodamasis pagalba, pasirūpinti savimi ir priimti kasdienius sprendimus sveikatos srityje, nes orientuojasi kieme; tiriamasis geba savarankiškai pasirūpinti savimi ir priimti kasdienius sprendimus dalyvaujant ūkinèje komercinèje veikloje, nes tikètina, kad jis supranta, kas yra ūkinè komercinè veikla, yra garbaus amžiaus ir turi fizinių sveikatos negalavimų, kurie riboja jo savarankiškumą, tikètina, kad dèl amžiaus ir sveikatos problemų jis jau nebeužsiims ūkine komercine veikla, jeigu ir turètų tokią teisę; tiriamasis geba

1 lentelè. Socialinių darbuotojų ir ekspertinès išvados dẻl asmens gebẻjimo pasirūpinti savimi ir priimti kasdienius sprendimus turtinių ir asmeninių neturtinių santykių srityse $(\mathrm{p}<0,05$, lyginant socialinių darbuotojų ir ekspertų išvadas).

\begin{tabular}{|l|c|c|}
\hline $\begin{array}{l}\text { Asmens gebėjimas pasirūpinti savimi } \\
\text { ir priimti kasdienius sprendimus }\end{array}$ & $\begin{array}{c}\text { Socialinių dar- } \\
\text { buotojų išvados } \\
\text { (N=171-100 } \\
\text { proc. })\end{array}$ & $\begin{array}{c}\text { Eksperti- } \\
\text { nės išvados } \\
\text { (N=171-100 } \\
\text { proc. })\end{array}$ \\
\hline $\begin{array}{l}\text { Geba pasirūpinti savimi ir priimti kas- } \\
\text { dienius sprendimus visose turtinių ir } \\
\text { asmeninių neturtinių santykių srityse }\end{array}$ & 6 proc. & 2 proc. \\
\hline $\begin{array}{l}\text { Geba iš dalies savarankiškai, naudo- } \\
\text { damiesi pagalba, pasirūpinti savimi ir } \\
\text { priimti kasdienius sprendimus visose } \\
\text { turtinių ir asmeninių neturtinių santykių } \\
\text { srityse }\end{array}$ & 13 proc. & 3 proc. \\
\hline $\begin{array}{l}\text { Visiškai negeba pasirūpinti savimi ir } \\
\text { priimti kasdienių sprendimų visose tur- } \\
\text { tinių ir asmeninių neturtinių santykių } \\
\text { srityse }\end{array}$ & 56 proc. & 46 proc. \\
\hline
\end{tabular}

2 lentelè. Socialinių darbuotojų ir ekspertinès išvados dẻl asmens gebejjimo pasirūpinti savimi ir priimti kasdienius sprendimus turtinių santykių srityse $(\mathrm{p}<0,05$, lyginant socialinių darbuotojų ir ekspertų išvadas).

\begin{tabular}{|l|c|c|}
\hline $\begin{array}{l}\text { Asmens gebėjimas pasirūpinti savimi } \\
\text { ir priimti kasdienius sprendimus }\end{array}$ & $\begin{array}{c}\text { Socialinių dar- } \\
\text { buotojų išvados } \\
\text { (N=171 - 100 } \\
\text { proc. })\end{array}$ & $\begin{array}{c}\text { Ekspertinės } \\
\text { išvados } \\
\text { (N=171 - 100 } \\
\text { proc. })\end{array}$ \\
\hline $\begin{array}{l}\text { Geba pasirūpinti savimi ir priimti kas- } \\
\text { dienius sprendimus visose turtinių san- } \\
\text { tykių srityse }\end{array}$ & 64 proc. & 36 proc. \\
\hline $\begin{array}{l}\text { Geba iš dalies savarankiškai, naudo- } \\
\text { damiesi pagalba, pasirūpinti savimi ir } \\
\text { priimti kasdienius sprendimus visose } \\
\text { turtinių santykių srityse }\end{array}$ & 68 proc. & 45 proc. \\
\hline $\begin{array}{l}\text { Visiškai negeba pasirūpinti savimi ir } \\
\text { priimti kasdienių sprendimų visose } \\
\text { turtinių santykių srityse }\end{array}$ & 48 proc. & 75 proc. \\
\hline
\end{tabular}


savarankiškai pasirūpinti savimi ir priimti kasdienius sprendimus, t. y. būti globèju (rūpintoju), pagalbininku pagal sutartị dèl pagalbos, priimant sprendimus, nes garbus amžius ir fizinès sveikatos negalavimai galètų būti kompensuojami socialinèmis paslaugomis).

Priimant ekspertinį sprendimą dèl veiksnumo/neveiksnumo tam tikrose gyvenimo srityse itin sudètinga būna „pasverti“ šizofreninio spektro sutrikimą turinčio asmens gebejjimą iš dalies suprasti savo veiksmų esmę ir juos valdyti tam tikrose srityse. Pagrindiniu argumentu priimant tokị sprendimą yra asmens gebejjimas ir motyvacija priimti pagalbą. Jei asmuo, atsižvelgiant į jo psichikos būklę, priima pagalbą, turi tam motyvaciją ir teikiama pagalba tam tikrose srityse kompensuos dèl psichikos sutrikimo prarastus jo gebẻjimus pasirūpinti savimi ir priimti kasdienius sprendimus, tokiais atvejais daroma išvada, kad asmuo iš dalies savarankiškai gali priimti sprendimus tam tikrose srityse su pagalba, sudarant sutarti su pilnamečiu fiziniu asmeniu, kuriuo jis pasitiki. O nesudarant tokios sutarties, tai yra neturint tokio asmens, yra teikiamos socialinės paslaugos, kuomet teismo pripažintas ribotai veiksniu tam tikroje srityje asmuo asmeniškai atsako pagal savo sutarties ir ne sutarties prievoles.

Esant skirtingoms ekspertų ir socialinių darbuotojų nuomonèms, itin apsunkinamas teismo sprendimo priemimas tokių asmenų atžvilgiu. Pažymètina tai, kad visais minètais atvejais, teismas prièmé sprendimą, vadovaudamasis teismo psichiatrijos ekspertizès išvadomis.

Asmens veiksnumo apribojimo procese ne mažiau reikšmingą darbą atlieka Neveiksnių asmenų būklès peržiūrèjimo komisija, kuri sudaroma iš 5 narių, atstovaujančių savivaldybès globos ir rūpybos institucijoms, gydytojo psichiatro, žmogaus teisių apsaugos srityje veikiančio atstovo ir socialinio darbuotojo. Pagrindinè šios komisijos užduotis yra neveiksnaus tam tikroje gyvenimo srityje asmens būklès peržiūra ir sprendimo prièmimas dèl tikslingumo kreiptis ị teismą dèl teismo sprendimo peržiūrẻjimo. Pažymètina, kad ši komisija savo veikloje turi vadovautis nešališkumu, nepriklausomumu, kuo mažesnio as-

3 lentelè. Socialinių darbuotojų ir ekspertinès išvados dèl asmens gebẻjimo pasirūpinti savimi ir priimti kasdienius sprendimus asmeninių neturtinių santykių srityse ( $<<0,05$, lyginant socialinių darbuotojų ir ekspertų išvadas).

\begin{tabular}{|l|c|c|}
\hline $\begin{array}{l}\text { Asmens gebėjimas pasirūpinti sa- } \\
\text { vimi ir priimti kasdienius sprendi- } \\
\text { mus }\end{array}$ & $\begin{array}{c}\text { Socialinių dar- } \\
\text { buotojų išvados } \\
\text { (N=171-100 } \\
\text { proc.) }\end{array}$ & $\begin{array}{c}\text { Ekspertinès } \\
\text { išvados } \\
\text { (N=171 - } \\
\mathbf{1 0 0} \text { proc. })\end{array}$ \\
\hline $\begin{array}{l}\text { Geba pasirūpinti savimi ir priimti kas- } \\
\text { dienius sprendimus visose asmeninių } \\
\text { neturtinių santykių srityse }\end{array}$ & 58 proc. & 32 proc. \\
\hline $\begin{array}{l}\text { Geba iš dalies savarankiškai, naudo- } \\
\text { damiesi pagalba, pasirūpinti savimi ir } \\
\text { priimti kasdienius sprendimus visose } \\
\text { asmeninių neturtinių santykių srityse }\end{array}$ & 52 proc. & 78 proc. \\
\hline $\begin{array}{l}\text { Visiškai negeba pasirūpinti savimi ir } \\
\text { priimti kasdienių sprendimų visose } \\
\text { asmeninių neturtinių santykių srityse }\end{array}$ & 53 proc. & 37 proc. \\
\hline
\end{tabular}

mens veiksnumo ribojimo ir pagristumo principais [7]. Atlikome keletą ekspertizių (7 atvejai) šizofrenijos spektro sutrikimų turintiems asmenims, kuriems minèta komisija pateike teismui išvadas, kad jų atžvilgiu skirti teismo psichiatrijos ekspertizę netikslinga, nes dèl turimo psichikos sutrikimo jie lieka visiškai negalintys suprasti savo veiksmų esmès ir jų valdyti visose gyvenimo srityse. Teismas, neatsižvelgdamas į šias rekomendacijas, vis dèlto paskyrè šiems asmenims teismo psichiatrijos ekspertizes. Buvome nemaloniai nustebinti komisijos išvadų pagrịstumu, nes visiems šiems asmenims, atlikus ekspertinį tyrimą, rekomendavome teismui pripažinti juos tik ribotai veiksniais, o kai kuriose gyvenimo srityse ir pripažinti veiksniais. Savaime kyla klausimas, o kaip gi tie, šizofrenijos spektro sutrikimus turintys asmenys, dèl kurių teismas besąlygiškai prièmė Neveiksnių asmenų būklès peržiūrèjimo komisijos rekomendacijas dèl teismo psichiatrijos ekspertizès atlikimo netikslingumo ir atlikdami teismo funkciją, nusprendè palikti juos neveiksniais visose gyvenimo srityse.

\section{Išvados}

1. Priimant ekspertinį sprendimą dèl asmens gebejjimo suprasti savo veiksmų esmę ir juos valdyti ịvairiose gyvenimo srityse asmenų, turinčių šizofrenijos spektro sutrikimų atžvilgiu, pagrindiniu vertinimo kriterijumi buvo klinikinis kriterijus, tai yra aktyvios psichopatologijos intensyvumo, sutrikimo eigos, gydymo efektyvumo, kritinių gebejjimų savo psichikos sveikatos atžvilgiu vertinimas bei socialinès adaptacijos lygis.

2. Tokiais atvejais, kai psichopatologija mažai išryškejjusi, labai svarbu remtis klinikinio vaizdo dinamika bei esama socialine adaptacija.

3. Apribojant asmens veiksnumą, metodiškai svarbu remtis tuo, kad kiekviena gyvenimo situacija kelia savo reikalavimus socialiai priimtinam elgesiui, todèl kiekvienos ekspertų išvados pritaikymas turi būti integralus, atsižvelgiant ị socialinio elgesio rizikos veiksnių prioritetus.

4. Net ryškius šizofrenijos spektro sutrikimus turintiems asmenims nèra būdingas totalinis socialinio elgesio sutrikimas, daugelis jų kasdienių veiksmu yra socialiai teisingi, todèl ekspertinèje praktikoje didelę reikšmę ịgauna racionalumo principas, kuomet ekspertai neabsolitizuoja neveiksnumo medicininio kriterijaus ir ekspertinius sprendimus priima atsižvelgdami į tai, kokias gy- 
venimo sąlygas turi tiriamasis, ar jam taikytos medicinos ir adaptacijos priemonès yra efektyvios ir ar šios priemonès padeda asmeniui adaptuotis visuomeneje.

5. Kaip rodo praktika, vertinant asmens savarankiškumą ivvairiose gyvenimo srityse, pasitaiko atvejų, kai nesutampa socialinių darbuotojų ir teismo psichiatrų ekspertų išvados, todèl teismas neretai turi sunkumų sprendžiant asmens veiksnumo apribojimo klausimus tam tikrose srityse. Manytina, kad tokios kolizijos priežastis yra nepakankama socialiniu darbuotojų patirtis šiais klausimais bei psichiatrijos žinių stygius.

6. Atsižvelgiant ị šio tyrimo rezultatus, galima teigti, kad šizofrenijos spektro sutrikimų turintiems asmenims institucine globa turi žymiai daugiau teigiamos įtakos užtikrinant šiu asmenų psichikos sveikatos stabilumą, gydymo tęstinumą, buitines ir socialines garantijas bei jų adaptaciją kasdieniniame gyvenime, palyginus su psichikos sveikata ir gyvenimo kokybe asmenų, gyvenančių savarankiškai.

\section{Literatūra}

1. Jungtinių tautų neigaliųų teisių konvencija ir jos fakultatyvus protokolas. Neigaliųjų teisių konvencija, 2010. Prieiga per internetą: https://e-seimas.lrs.lt/portal/legalAct/lt/TAD/ TAIS. 335882

2. Jungtinių tautų Generalinės asamblejjos Visuotinè žmogaus teisių deklaracija, 1948. Prieiga per internetą: https://e-seimas.lrs.lt/ portal/legalAct/lt/TAD/TAIS.278385

3. Europos žmogaus teisių ir pagrindinių laisvių apsaugos konvencija, Roma, 1950. Prieiga per internetą: https://e-seimas.lrs.lt/ portal/legalAct/lt/TAD/TAIS.19841

4. Europos Tarybos Ministrų Komiteto rekomendacija Nr. R(99) dèl Pilnamečių neveiksnių asmenų apsaugos principų, 1999.

5. Lietuvos Respublikos civilinis kodeksas. Vilnius; 2000. Prieiga per internetą: https://www.e-tar.lt/portal/lt/legalAct/ TAR.8A39C83848CB

6. Lietuvos Respublikos socialinès apsaugos ir darbo ministro 2015-12-10 įsakymų Nr. A1-742 patvirtintas asmens gebejjimas pasirūpinti savimi ir priimti kasdienius sprendimus nustatymo tvarkos aprašas. Prieiga per internetą: https://e-seimas.lrs.lt/ portal/legalAct/lt/TAD/7b137b209f8111e591078486468c1c3 9?jfwid=-4cu9uc4dx

7. Lietuvos Respublikos civilinis kodeksas. Neveiksnių asmenų peržiūrèjimo komisija, Vilnius, 2015. Prieiga per internetą: https://www.infolex.1t/ta/20799:str2.10-1

\section{LIMITATION OF LEGAL CAPACITY OF INDIVIDUALS WITH SCHIZOPHRENIA SPECTRUM DISORDERS}

\section{J. Daškevičienė, K. Daškevičius, G. Navickaitė}

Key words: forensic psychiatric examination in civil cases, declaration of legal incapacity in natural persons, limitation of legal capacity.

Summary

Legal capacity is the most important element of a legal personality, related to the person's ability to perform certain actions. All people, including those with mental disorders, participate in civil legal relations, therefore, forensic psychiatric expertise is crucial in the civil process as experts assess the person's social functioning and actual real-life adaptation. In 2016 amendments to the $\mathrm{Ci}$ vil Code of the Republic of Lithuania regarding the recognition of a natural person as legally incapacitated to a specific degree entered into force. Subsequently, all cases and court rulings where a person was declared to be legally incapacitated prior to the 2016 the amendments were decided to be reviewed and new legal capacity limitations to a specific degree set for persons with mental disorders. The aim of our work was to evaluate the mental health of persons with schizophrenia spectrum disorders for whom the civil process was started to limit their legal capacity or review previous court rulings, and to distinguish the main criteria for assessing such person's ability to understand the meaning of actions and controlling their actions in particular areas of life. It has been determined that the main evaluation criterion is clinical, which comprises of assessment of the intensity of the active psychopathology, course of the disorder, treatment effectiveness, critical ability to assess one's mental health and level of social adaptation. The study also found that institutional care for people with schizophrenia spectrum disorders has a much more positive effect on sustaining the stability their mental health, the continuity of treatment, domestic and social guarantees as well as their adaptation in their everyday life, as compared to mental health and quality of life of people with schizophrenia spectrum disorders living by themselves. When deciding on the person's ability to partly understand the essence of their actions and to manage them, the person's ability and motivation to receive help was a key determinant for this diagnostic group of individuals. In conducting this type of expert examination, forensic psychiatry experts must follow the provision on the preservation of the person's maximum legal capacity.

Correspondence to: info@ntpt.lt

Gauta 2019-01-04 